\title{
Green Energy in the Light of Metaphors and Metonymia in Environmental Sustainability Discourses
}

\author{
Priscilla Chantal Duarte Silva \\ $\mathrm{PhD}$ in Linguistics and Portuguese Language \\ Professor of Federal University of Itajubá - Brazil \\ Maria Clotilde Almeida \\ Phd in Germanic Linguistics \\ Professor of University of Lisbon - Program in Culture and Communication \\ Faculty of Humanities of the University of Lisbon \\ Senior Researcher in Cognitive Linguistics - University of Lisbon \\ Post doctoral student in Communication and Program Discourses in Culture and Communication-FLUL ${ }^{1}$

\begin{abstract}
The main objective of this study is to investigate the conceptual construction of environmental sustainability from the semantic analysis of the conceptual metaphors that constitute it, as well as to assess the contribution of these metaphors to the linguistic argument in these texts. For this purpose, it is adopted as methodological bias the collection of a linguistic corpus from of Brazilian and Portuguese newspapers texts focused on environmental sustainability for the realization of a linguistic-discursive analysis of cognitive nature and qualitative and quantitative nature. From the qualitative results obtained, we can access the argumentative conceptual tools called for the persuasion of the common reader about the improvement of the practices of protection of the environmental resources. There is also the constitution of an epiddical discourse in the sense of exaltation to natural resources and the need to produce clean energy. Pragglejaz group's (2007) Metaphor identification procedure (MIP) analysis method was used to identify metaphors in a corpus and Charteris-Black's Critical Metaphor Analysis (2004) to identify the statistical resonance of the main conceptual domains found in these. The results indicate that the conceptual metaphor can be identified as part of the argument of these texts and there are more activated conceptual domains than others. It is concluded that metaphors on this environmental theme are used as part of the conceptual system and for persuasive purposes.
\end{abstract}

Keywords: environmental sustainability, cognition, argumentation, metaphor and metonymy, conceptual metaphor.

\section{Introduction}

The phenomenon of metaphor is understood in the more traditional approaches of metaphor as a process of analogical construction, in which the use of a certain term and its meaning to the detriment of another occurs. Hence the correlation with semantic "change" and "transposition", according to the etymology of the word. However, the phenomenon involves typically cultural issues, given that "the meaning is partly in what one has in mind and partly in the reception that words receive in the reader's mind" (Brown, 2003, p.16). In this sense, it cannot be denied that the understanding of metaphor is linked to the way people interpret it.

In the field of Science, as well as conceptualizing the world, metaphors are also used in an attempt to understand the world (Brown, 2003).Many concepts are traced by scientists through metaphors, such as: time, quantity and energy are understood from embodied experiences. In this sense, linguistic constructions of the type are commonly found: "Energy is a surface", "time is a linear dimension", or even, as social experiences "The cell is a factory", as highlighted by Brown (2003, p.160).

\footnotetext{
${ }^{1}$ Maria Clotilde Almeida - Supervisora de pós- doutoramento

Phd.in LinguisticandCLUL Researcher

Professor of the Program in Culture and Communication - FLUL

FLUL/CLUL/Memberofthe Mind-BrainCollege

maria.almeida@campus.ul.pt

Supervisor
} 
In speeches about the environment, environmental sustainability or climatic conditions, concepts such as: "the Amazon is the lung of the world", "Green buildings", "blue planet", "The earth is a living organism", among others focused on environmental issues. Whether it is of a political nature with an argumentative and propagandistic bias for the purposes of its own interests, whether of a scientific nature or of environmental education, environmental metaphors appear as a new way of building meaning. Maciel \& Silva (2011) remember that the green color has come to mean the life of nature as a kind of metaphorical mechanism. Many companies started to carry the "we are green" banner, or even the term "sustainability", together with the brand.

The theoretical framework of this study is based on the theory of conceptual metaphor. In principle, conceptual metaphors are part of the conceptual apparatus shared by speakers of the same culture (Brown, 2003). Usually, there is a correspondence relationship between the source and target domains from common experiences. The aim of this study is to analyze the phenomenon of metaphor from a cognitive perspective, in order to locate metaphors in their argumentative chain of environmental sustainability.

\section{The argumentation from the cognitive point of view}

For Perelman's classic argument (1999), argumentation implies an action to transform the listener. Persuasion is also involved on this issue. Much more than trying to convince and accept the listener, persuasion seeks to act discursively on someone. Often, the argument is linked to problem solving, to reasoning, especially when there are differences of opinion. And for that reason, it has a "[...] crucial role in all areas of public life" (Van Eemeren, 2017, p.323).

Considering the object of analysis of this study, the speeches about environmental sustainability, produced by means of metaphors, are in between the deliberative in order to persuade for the preservation and conservation of nature and the epididical for promoting an exaltation of what corresponds sustainability practices with the same objective.

As Perelman (2005, p.169) argues, "the argumentative intention is the use of a term that deviates from the usual language". It is in this context, therefore, that the metaphor fits. To act as an example and rhetorical force the idea of the need for environmental preservation and conservation. "There is no neutral choice" (Perelman, 2005, p.169). Therefore, to the extent that metaphor is used in scientific discourses involving the theme of sustainability, it is possible to verify the role of metaphor as an argument. As for the argumentative analysis 'to observe the epidictic speeches as those that appeal to values that he praises. Its core is seen as axiological, whose function is to sustain the sense of community. In this way, it is believed that when reinforcing ideas such as: "Be a green consumer; "Buy green electricity where you can; Make the decision to live a carbon-neutral or carbon-free life"

For Perelman (1996), different from what Aristotle thought, epididical discourses have the effect of building an intention to amplify common values through metaphors. These speeches have a serious character of creating a communion around certain events, certain people, certain achievements, whose valorization characterizes the culture of a society. In the line of reasoning of the rhetorical tradition, the metaphor consists of a trope, that is, the transformation from one meaning to another. This is only possible according to Perelman (2005) due to "a comparison that exists in the mind". In this respect, it is worth emphasizing the cognitive character of the metaphor, as coming from a mental capacity to build comparative relationships and establish certain parameters of meaning.

In the excerpt from Table 1, it is possible to observe how the notion of "law" in "laws of nature" acts in the same purpose of extension of meaning. Although it is not an entity, nature is assigned a "function" of having its own rules or laws under which man is subject. Hence the implicit relationship of dependency or slavery. From there it is still possible to extract the conceptual metaphor NATURE IS LAW.

Table1 - The laws of nature and sustainability

\begin{tabular}{|l|}
\hline NEWSPAPER_O PÚBLICO / Portugal \\
\hline Opinion/ Maria Amélia Martins-Loução/ 11 de February 2019, 6:35 \\
\hline THE LAWS OF NATURE AND SUSTAINABILITYThe present "development" proposals for \\
the Tagus and Sado estuary are just a few examples of how economic and political interests \\
trample the safeguarding of protected wetlands.
\end{tabular}

Source: https://www.publico.pt/2019/02/11/ciencia/opiniao/leis-natureza-sustentabilidade-1860653

\footnotetext{
${ }^{2} \mathrm{Al}$ Gore (former US president, journalist and advocate for environmental issues), for example, is inserting arguments that will form a sustainable culture.
} 
In the excerpt below, the so-called "Sustainability is not fashion. It is a guarantee of the future "is built under a process of conceptual metaphorization that SUSTAINABILITY IS FUTURE observed from the lexical choices of the statement. When exhibiting SUSTAINABILITY IS NOT A FASHION, or SUSTAINABILITY IS NOT A PASSENGER, it is possible to realize that it is not a concept that should be seen as a passenger, just as fashion sets in. After all, fashion is unstable, varies very easily and is something that is much discussed. For example, if something is in fashion everyone knows and everyone comments. In this respect, the term should be fad. However, the transposition to MODA broadens the concept and gives rise to these interpretations. Hence the metaphor IS NOT FASHION, having as reference its instability. In this sense, together with the next sentence: It is a guarantee of the future, the reader is able to interpret the semantic architecture of the argument. The second sentence being the justification for the first. Thus, the interrelationship between the two clauses complements the argument.

For Perelman (2005), the choices were not neutral. Thus, SUSTAINABILITY IS FUTURE is a conceptual metaphor, being a derivation of SUSTAINABILITY IS A FUTURE GUARANTEE. In this respect, the reader can infer from the title and the lead that there is a commitment, a concern with sustainability for survival reasons. After all, looking for sustainable means is to protect and safeguard natural resources, that is, a way to guarantee the future as the author defends.

Table 2 - Sustainability is not fashion. It is guarantee of future

\begin{tabular}{|l|}
\hline NEWSPAPER_O EXPRESSO / Portugal \\
\hline 09/09/2019/ Society \\
\hline SUSTAINABILITY IS NOT A FASHION. IT'S A FUTURE GUARANTEE \\
Xander Bueno de Mesquita was the great speaker of the morning at the Towards a Sustainable \\
Tourism Industry conference, which is taking place today at Estufa Fria, in Lisbon. The Hotel QI \\
Amsterdam is a 100\% sustainable project that was born from the entrepreneur's vision \\
Express Projects. Portugal aspires to have 97\% of the companies committed to the goals set for \\
the management of water, energy and waste by 2027. However, there is still a lot to do on the path \\
of sustainability, THAT SURVIVAL ISSUE. \\
In the same vein, Luís Araújo, recalls that SUSTAINABILITY IS NOT JUST \\
COMPETITIVENESS, BUT A QUESTION OF SURVIVAL. "IF WE DO NOTHING \\
DIFFICULTLY WE WILL HAVE SOME FUTURE", he says. For the person in charge of \\
Turismo de Portugal "we all have to be more demanding, every day" so that society can be \\
involved in these issues. \\
The message he leaves to businessmen in the sector is the emergence of reflecting on the best \\
solutions for the planet and for communities, for a joint work because SUSTAINABILITY IS \\
EVEN A MATTER OF SURVIVAL OF THE SPECIES. \\
\hline
\end{tabular}

Source: https://expresso.pt/sociedade/2019-09-09-Sustentabilidade-nao-e-moda.-E-garantia-de-futuro

In the body of the text, from the excerpt from Table 2, it is noted that once again the conceptual metaphor is used to compose arguments. In: "there is still a lot to do in the path of sustainability, this issue of survival", it can be observed that SUSTAINABILITY IS SURVIVAL under the claim of a conditional that only the possibility of maintaining life if something is done. This can be proven by reading more excerpts from the same text in the article, as in: "if we do nothing, we will hardly have any future".In the same way, in "sustainability is really a question of survival of the species", the relationship between sustainability and human survival is confirmed. Furthermore, it is also possible to observe that the term "species" in this context acts as a metonym for humanity. In "sustainability is not just competitiveness [...]", it can still be seen that SUSTAINABILITY IS COMPETITION, a conceptual metaphor widely used in green marketing discourses.

According to Lakoff and Johnson (1980), the metaphor consists of two conceptual domains: a source and a target domain. The source domain is responsible for categorizing concepts that determine what is meant about the target domain. Thus, in the face of SUSTAINABILITY IS SURVIVAL, there is the conceptual metaphor SUSTAINABILITY IS LIFE, as the meaning of the statement unfolds. Therefore, there is a source domain: sustainability and all the concepts linked to it and a target domain like life, for example. The choice for one of these concepts is directly linked to the context in which the statement appeared. It is the context that circumscribes the action of the metaphor. Therefore, in cognitive terms, the argument in the speeches in which the theme of sustainability appears focuses on the formation of a network of conceptual metaphors, in which the metaphor or metonymy consists of the argument itself. The argument, from a cognitive point of view, can be seen from these unfolding of conceptual maps that interrelate to form the semantic chain. The argument can be understood from the interface between the target and source domains.

Tseronis \& Forceville (2017) share the same idea when they state that, in fact, the argument involves opinion because it is linked to the constitution of premises for the defense of a point of view. 
However, the authors emphasize that argumentation can be studied as a product (premises that support a conclusion), process (communicative and interactional activity) or their combination.

In the excerpt below, Table 3, "Solar energy: a new energy for the business", the term "energy" in the excerpt "a new energy for the market" reveals a conceptual metaphor behind the statement, since it is used to engender the meaning of "strength", "impulse", or "raise", "increase" business profits. Hence, one can understand the conceptual metaphor that ENERGY IS STRENGTH as a constituent part of what is argued in the statement.

The word "energy", in its most scientific character, is in itself abstract. Traditionally known and used by engineering as the ability to do work as something capable of generating a certain force in a body, the word "energy" does not have a concrete reference, that is, it is not tangible, visible or embodied. However, it is felt, perceived and even measured. Within a context as in the excerpt shown below, it can be used to generate such a meaning: SOL IS ENERGY $\rightarrow$ SOLAR ENERGY $\rightarrow$ ELECTRIC ENERGY $\rightarrow$ PROFIT $\rightarrow$ GREATER COMPETITIVENESS.

After all, if the sun is energy and it generates solar energy that can be replaced by electricity, which in turn generates greater savings with electricity, therefore, there is profit generation and with this there is greater competitiveness because it will be possible to produce more at a lower cost. This can be confirmed by the argument that follows throughout the text, especially to complete the argument, based on the proposition that SOLAR ENERGY IS A NEW ENERGY FOR BUSINESS in: "More than a third (35\%) confirmed that their companies already produce a part of the energy they consume and, of these, 6 out of 10 companies bet on solar energy "which acts as a justification for the title itself, claiming that once companies are able to produce at least part of the energy that they consume every day, this already represents a significant profit for them.

From reading both the title of the article and the text in its entirety, the reader will arrive at the metaphor SOLAR ENERGY IS MOVEMENT, that is, it is a source of profit for business, which moves / activates companies. In this case, the repetition of the term "energy" was intentional in order to obtain a duplicity of the signifier but with another meaning. Thus, it can be inferred from the conceptual metaphors of the verbal element itself that it is possible to infer that there is the possibility of formulating a mental image, even if abstract.

\section{Table3 - SOLAR ENERGY: A NEW ENERGY FOR BUSINESS}

\begin{tabular}{|l|}
\hline NEWSPAPER_O PÚBLICO / Portugal \\
\hline [estúdio] P/ 17 de September 2019, 8:40 \\
\hline SOLAR ENERGY: A NEW ENERGY FOR BUSINESS \\
\hline Producing solar energy is an increasingly competitive way of reducing the electricity bill. In 2050, solar and \\
wind energy will be responsible for the generation of 50\% of electricity in the world, ending the dominance \\
of fossil fuels in the energy sector. The preview is from Bloomberg NEF (New Energy Finance) in the New \\
Energy Outlook 2019 report, which also predicts that solar energy will see the greatest growth: from the \\
generation of 2\% of the world's electricity today to 22\% in 2050. In short, the fundamentals of the electrical \\
system will be redesigned due to the decreasing cost of batteries and renewable energy, with emphasis on \\
solar energy.
\end{tabular}

Source:https://www.publico.pt/2019/09/17/estudiop/artigo/energia-solar-nova-energia-negocio-1885790

\section{Environmental Sustainability And Media Speech}

Terms such as sustainable development and ecological awareness for future generations are being increasingly discussed and gaining adherents. Society then demands products that do not compromise the environment. The term "green company", then, was adopted to be synonymous with the company that is committed to the environment.

In a way, this influences man's perception of the world. In many ways, the perception that SUSTAINABILITY IS LIFE was created, that is, a metaphor around a culture aimed at preservation and conservation for future generations, as well as everything that has become a consequence of this in terms of products and by-products. In this sense, sustainable discourses in the media began to emerge in order to propagate, through an epididical discourse, a "green" philosophy, that is, focused on environmental concerns, especially with regard to impacts. This was due to climate change, scarcity of natural resources, which in turn caused the demand for mitigation and the search for renewable energy and more sustainable solutions.

In this regard, much is discussed about sustainable development, which is recognized as the process of meeting needs without harming future generations (Nilashi et al., 2019). For this reason, all speeches around sustainability emphasize this characteristic of thinking about solutions for preservation and conservation for the future of the next generations. 
In a way, this will even reflect on how the metaphors present in these speeches are produced. The three pillars of sustainable development are economic, environmental and social (Finkbeiner et al., 2010).

The authors believe that the preservation and conservation of the environment is the prerequisite for the other pillars. However, there is evidence that questions about sustainability started in the 1960s, when they began to take on political form and then became more popular.

In the theory of conceptual metaphor it is seen how to conceptualize one domain in terms of another. In the field of Sciences Cuadrado-Esclapez et al (2016) in the light of Fahnestock's work (1999) on rhetorical figures in Sciences, they point out that metaphor is one of the dominant resources employed by the human mind to reflect the scientific phenomenon and describe it. Traditionally, metaphor includes the transposition of meaning by similarities of aspects. However, for Cognitive Linguistics, the metaphor does not consist of just similarity, but is created by the cognitive mechanism or system. Metonymy, according to Cuadrado-Esclapez et al (2016), is another type of cognitive mechanism that occurs when a semantic or characteristic part of an entity serves to name the entire map. It usually establishes cause and effect or part-whole relationships. Metonymy engages a semantic or characteristic part of the source domain.

In the table below, it is possible to observe how the term "green" has become not only a metaphor in the sense of sharing similarities in the domain of color representing nature, qualifying the nouns that follow it, but also a metonymic construction in the sense of being part of a set that make up the field of sustainability.

The green color in these contexts has a metaphorical effect of using one term in place of another while representing a part of sustainability. In this sense, being "green" or doing something "green" therefore consists in being part of a given set of characteristics that qualify what belongs to the group of what is sustainable."Green consumption" in the context below is not about making reference to consuming something green, like vegetables, for example, but about a form of consumption that is closest to sustainable principles. In this way, GREEN CONSUMPTION IS SUSTAINABLE CONSUMPTION, or even be sustainable. However, the association with the word green is related to a kind of "color" of nature. And nature is associated with sustainability.It is believed that due to the fact that most people associate the memory of nature with trees, mostly plants and grass, the term "green" has gained strength in language as a semiotic and metonymic index for nature and, consequently, with environmental sustainability.

Larson (2011) suggests that it is necessary to reflect on the role of metaphor for the development of sustainability, the authors of this study assume that the metaphors of sustainability contribute to the propagation of the values of preservation and conservation of the environment environment, since they act cognitively as argumentative elements directed to the epididical discourse of valuing nature. In this perspective, the use of "green", either as a metaphor or metonym helps in the construction of a sustainable concept, that is, they conceptualize through the word "green" the principles that surround the term "sustainability".

Table 4 - Green consumption: expert answers ten questions for a more sustainable day to day.

\begin{tabular}{|l|lll|}
\hline NEWSPAPER_O GLOBO / Brasil & & \\
\hline Luciana Casemiro \\
02/08/2013 - 09:00 / uptaded in 04/06/2019 - 12:46 \\
\hline $\begin{array}{l}\text { GREEN CONSUMPTION: SPECIALIST ANSWERS TEN QUESTIONS FOR A MORE } \\
\text { SUSTAINABLE DAY TO DAY }\end{array}$ \\
\hline $\begin{array}{l}\text { João Paulo Amaral, from Idec, shows that small daily actions, such as removing electronic devices from the } \\
\text { socket, can make a difference }\end{array}$ \\
\hline
\end{tabular}

Source:https://oglobo.globo.com/economia/defesa-do-consumidor/consumo-verde-especialista-responde-dezperguntas-para-um-dia-dia-mais-sustentavel-9290985

First of all, it is necessary to understand the concept of sustainability Ayes, Van den Bergh and Gowdy (1998) and the reason for the relationship with the color green. The concept of sustainability originated in the context of renewable resources and was later adopted as a slogan by environmental movements (Sharachchandra, 1991).

A relevant case of the term "green" is the use of it as an embodiment. Larson $(2011$, p.58) points out that "personification is a form of metaphor" by which elements of the human being to a non-human being are used. According to the author, anthropologists have shown that many cultures have personified the natural world. He also points out that the environment is part of man, and therefore the world is animated. Therefore, personification is a way of relating to the world. In Table 5, it is observed that Amzônia is classified as the lung of the world, a metaphor already crystallized, but mistakenly used, since much of the planet's oxygenation comes from seaweed. In "the lungs that produce $20 \%$ of the planet's oxygen is on fire", it is noted that in addition to being a conceptual metaphor considering the domains of lung (human organ) - oxygen and lung (representation of forests) - oxygen through of the photosynthesis process, a personification relationship is also outlined considering the Amazon as a human organ. 
Table5 - A "internacionalização da Amazónia": uma estratégia neocolonial?

\begin{tabular}{|l|}
\hline NEWSPAPER_O PÚBLICO / Portugal \\
\hline 12/09/2019/Carlos Blanco de Morais/Opinion \\
\hline THE "INTERNATIONALIZATION OF THE AMAZONIA": A NEOCOLONIAL STRATEGY? \\
\hline With the crackle of the rainforest, the simplistic nature of the television reduced the crisis in the Amazon to \\
a Macron philanthropist and savior of the "LUNG OF THE WORLD" and to a diabolical Bolsonaro who \\
commits "ecocide". The topic deserves some synthetic answers to five pertinent questions.1. Is the Amazon \\
the LUNG OF HUMANITY? When Macron posted that "The Amazon rainforest, THE LUNGS THAT \\
PRODUCE 20\% OF THE PLANET'S OXYGEN, IS IN FLAMES", the message became a dogma of faith \\
when it was multiplied by the international jet set on the networks, with photos of forests in flames.
\end{tabular}

Source:https://www.publico.pt/2019/09/12/mundo/opiniao/internacionalizacao-amazonia-estrategianeocolonial-1886114

In this case, the conceptual metaphor "THE AMAZON IS THE LUNG OF THE WORLD" or "THE AMAZON IS THE LUNG OF HUMANITY", is constituted by the fact that the lungs are the main organs of the respiratory system. "In the lungs, oxygen is transferred from the air to red blood cells and carbon dioxide is released from the blood to the outside. These gas exchanges are called respiration"(CUF, 2019). Analyzing the context, it can be observed that the journalistic text criticizes the situation of the fires that occurred in the Amazon to discuss how the subject is treated by the media and also explores the concept through conceptual metaphors to attract supporters.

\section{Methodology}

A corpus was composed based on a database analysis with textual data from discourses of 15 online journalistic texts, 8 Portuguese and 7 Brazilian, for the composition of a selected analysis corpus, as a criterion the presence of the sustainability theme especially in terms of the terms "energy" and "sustainability". Discourse analysis was used to understand the argumentative scope of online journalistic texts to analyze the argumentation in the epididical discourse. Metaphors were identified using the MIP method - Metaphor identification procedure, by Pragglejaz group (2007), which uses selection of metaphorical items of words in a text from the literal meaning of the words.

For this, the Portuguese language dictionary Priberam / https://dicionario.priberam.org/ was used. The Critical Metaphor Analysis methodology by Charteris-Black (2004) was used to identify the resonance. Some excerpts from the journalistic articles were inserted, selected from the corpus of analysis, according to the length of the texts.

\section{Analysis of online sphere journalistic texts about environmental sustainability and green energy}

"Green energy" is that generated from renewable resources. At first it can be mistaken as a synonym for clean energy. However, hydroelectric energy and that obtained from firewood are considered renewable, but not clean. According to Berman (2007), he argues that hydroelectric plants also emit greenhouse gases, particularly methane, due to the decomposition of vegetation cover submerged definitively in the reservoirs. Therefore, everything suggests that what led to the concept of clean energy is related to the least possible environmental impact. Such notions are relevant to understand the semantic system generated around the term sustainability, as well as its manifestations in metaphorical and metonymic forms. Arrows $(\rightarrow)$ are used to indicate the correlation of a term referring to another in the argumentative chain to understand the metaphor or metonymy in the argumentative process.

The author draws a comparative parallel between effectiveness and the breaking of paradigms between the types of fossil energy and clean energy. However, he points out that there are not enough arguments, when saying "But the arguments leave a lot to be desired", when they argue that combustion engines pollute less than electric ones. The author points out that there are defenders on both sides, but that the clean energies actually win. 
Table6- Combustion engines pollute less than electric? Stop the delusions

\begin{tabular}{l}
\hline NEWSPAPER_OBSERVADOR / Portugal \\
\hline 21/8/2019, 23:582.98137 \\
\hline COMBUSTION ENGINES POLLESS LESS THAN ELECTRIC? STOP THE DELIGHTS \\
\hline \\
Another faculty, this time Spanish, is involved in the discussion between HARMFUL EMISSIONS FROM \\
VEHICLES WITH COMBUSTION ENGINES and their competitors with ELECTRIC MOTORS \\
POWERED BY BATTERY. But the arguments leave a lot to be desired. \\
\hline Among motorists, there are fans of electric vehicles and, with equal vehemence, there are others who defend \\
combustion engines. Both solutions have advantages and disadvantages, perfectly defensible, BUT \\
ARGUMENT THAT COMBUSTION ENGINES, OR SPECIFICALLY DIESEL ENGINES (AS ALSO \\
DEFENDED A GERMAN STUDY), emit less CO2 - basically, PLAYING WITH THE TERMS to mislead \\
the public [...]. The Spanish Association of Automobile Professionals (ASEPA) publishes a study by the \\
Polytechnic University of Valencia, where the four researchers who sign the work argue that modern \\
combustion engines, whether gasoline or diesel, have evolved immensely and ARE TODAY AN \\
EXAMPLE OF "CLEANING" in terms of harmful emissions and only THE INFORMATION BODIES \\
together with other market players "are responsible for claiming YOUR PREMATURE DEATH.
\end{tabular}

Source:https://observador.pt/2019/08/21/motores-de-combustao-poluem-menos-que-electricos-parem-com-osdelirios/

For Kovecses (2006), the source or source domain is the one used to understand another conceptual domain (the target). The source ones are generally less abstract than the target or target domain. The target or destination domain, on the other hand, is the domain with which the other helps. Target domains are generally more abstract than source domains. In the classic example "life is a journey", the life domain is the target because it is necessary to first understand what is in the "travel" domain that can be transferred to the life domain, which is more abstract than travel.

Note that for the title, there are the following metaphoricalities: COMBUSTION ENGINES IS FOSSIL ENERGY / ELECTRIC MOTORS ARE CLEAN ENERGY. And if the polluting energy of combustion engines is equivalent to clean energy, this is a DELIGHT. Therefore, DELÍRIO IS LIE or SOMETHING IRREAL. In other passages one can also find conceptual metaphors such as "battery powered electric motors", so one can extract the conceptual metaphor BATTERYIS FOOD or MOTORS ARE LIVING BEINGS, a kind of personification. In "harmful emissions from vehicles with combustion engines" COMBUSTION ENGINE IS DAMAGE. In, "but to argue that combustion engines, or specifically diesel engines (as a German study has also argued)", there is ARGUMENT IS DEFENSE, or still, ARGUMENT IS FIGHT or DISCUSSION IS WAR. In "playing with terms to mislead the public", there are WORDS ARE GAMES. In "the organs of information" there is INFORMATION IS BODY. It is noted, therefore, that the conceptual metaphor tends to appear, in the journalistic verbal text, from the formulation of the arguments, often acting together.

In "[...] today they are an example of 'cleaning"' we can observe the argument that combustion engines have evolved and considerably reduced the polluting effect and today they no longer emit polluting gases, being, therefore, less polluting that electric cars as it questions the title of the story. In this way, it is possible to arrive at the COMBUSTION ENGINES ARE ALREADY CLEAN ENERGY. However, the quotation marks of the word "cleanliness" indicate a certain irony once again considering the context in which the author is criticizing the study of researchers who treat combustion energy as a form of clean.

In YOUR PREMATURE DEATH, there is another metaphorical construction that concerns the end of the use of fossil fuels, or even combustion engines. In this case, the metaphor arises from the analogue relationship between premature death of a baby, for example, with death / hasty elimination of the combustion engines. In this case, concept maps are established in two domains: human and motor, in which, once death is the elimination of life or existence, the author considers that the early / precipitous or reckless elimination of combustion engines is not a good attitude.Thus, it can be said that the central domains from which they activate the argumentative chain are: death referring $\rightarrow$ elimination of life and the elimination of combustion engines $\rightarrow$ premature death $\rightarrow$ baby $\rightarrow$ combustion engines $\rightarrow$ out of time $\rightarrow$ precipitated. 
In this context, it can be observed that there is an unfolding of interpretations until reaching the metaphor that ELIMINATION OF COMBUSTION ENGINES IS PREMATURE DEATH. Just as in premature death babies are outside the expected time, it is believed that the author's argument is, due to polysemy, showing that combustion engines should not be eliminated, since they claim that they are "clean" and even more so than electric motors.

As Bonhomme (1998) recalls, persuasion is necessary for an argumentative discourse to be rhetorical. In this case, the excerpt from table 7 reveals that persuasion occurs in terms of arguments aimed at environmental sustainability, as it defends the idea that combustion engines will never be better than electric ones and explicitly criticizes "leading you to think that are less polluting - it is ridiculous to say the least "the fact that researchers intentionally say and persuade the public that this is possible.

In the excerpt from Table 7, the terms "clean energy" and "green investment" act as metaphorical constructions to qualify the type of energy, in the first, and the sustainable model in the second. In the case of "clean" the metaphor is generated around the type of renewable energy with which it is intended to work. Analyzing the context of the journalistic article, it is observed that the collaborative financing platform intends to attract investors who intend to raise investment funds.

Table7 - Collaborative financing platform hoursers bets on renewables

\begin{tabular}{|l|}
\hline NEWSPAPER_EXPRESSO / Portugal \\
\hline Economy/ 11.09.2019 às 12h13 \\
\hline HOURSERS COLLABORATIVE FINANCING PLATFORM BET ON RENEWABLES \\
\hline Housers, a crowdfunding platform, or collaborative financing, which has been dedicated to real \\
estate investments, has decided to invest in renewable energies and will offer GREEN \\
INVESTMENT opportunities starting at 50 euros, the company said in a statement. Investors will \\
be able to invest in the same platform in real estate projects and in renewable energy and \\
environmental sustainability projects, related to solar energy, energy efficiency and CLEAN \\
ENERGY". \\
\hline
\end{tabular}

Source: https://expresso.pt/economia/2019-09-11-Plataforma-de-financiamento-colaborativo-Housers-aposta-nasrenovaveis

The term "green" is assigned as an adjective to metaphorically represent a type of investment that involves environmental sustainability, especially linked to the generation of clean energy, that is, it refers to a sustainable practice. However, it can also be understood as a metonym if thought of as a term that includes all forms of investments that involve environmental sustainability. In this case, for the author there is no semantic difference between clean, renewable and green energy. Although in the excerpt "investors will be able to invest in the same platform in real estate projects and in renewable energy and environmental sustainability projects, related to solar energy, energy efficiency and clean energy", they appear as different concepts, in the lead of the article in "Project of crowdfunding, which has already raised 5 million euros in Portugal, mainly for real estate investment, will now offer financing options for clean ENERGY projects "the term" clean "encompasses all classifications.

It is noted, therefore, that the semantic construction of the text uses metaphorical resources, especially the mappings. In this context, from the examples and concepts it is possible to arrive at a metaphorical construction: SOLAR ENERGY IS RENEWABLE ENERGY $\rightarrow$ RENEWABLE ENERGY IS CLEAN ENERGY $\rightarrow$ CLEAN ENERGY IS GREEN INVESTMENT $\rightarrow$ GREEN INVESTMENT IS SUSTAINABILITY $\rightarrow$ SUSTAINABILITY IS GREEN ENERGY IS GREEN ENERGY PROTECT THE ENVIRONMENT. Note that from the argumentative chain it is possible to arrive at the metaphor. From the term investment linked to renewable energy, clean energy and green energy, we have the idea of investment linked to sustainability.

In the excerpt from Table 8, below, energy sustainability is discussed around the generation of energy using solar panels. The news story reports that the Disney World solar facility will spread enough energy to supply 10,000 homes a year in addition to reducing greenhouse gas emissions. In effect, it generates a speech with the argument that the initiative will help Disney to reduce gas emissions. Therefore, there is a discourse that defends sustainable practices in favor of environmental quality, especially when it claims that the energy generated will not be directed to Disney theme parks, but to local supply. 
Table8 - Disney parks will get greener

\begin{tabular}{|l|}
\hline NEWSPAPER_O GLOBO / Brasil \\
\hline NYT/13/10/2018 - 16:59 / Updatein 13/10/2018 - 18:45 \\
\hline DISNEY PARKS WILL GET GREENER \\
\hline $\begin{array}{l}\text { In all of our facilities around the world, we are investing in HIDDEN MAGIC to continually reduce our } \\
\text { environmental impact [...]. Disney is EMERGING AS A RENEWABLE ENERGY FORCE. }\end{array}$ \\
\hline $\begin{array}{l}\text { Disney's move towards CLEANER ENERGY comes at a time when the brand image of GLOBAL GIANTS } \\
\text { needs to go much further, say, on a ride on Space Mountain [...] }\end{array}$ \\
\hline [...] But the search for green solutions didn't always work at Disney. In 2015, when TRIED, FOR THE \\
FIRST TIME, “TURN GREEN" YOUR BUS FLEET, the executives thought that the solution could be the \\
electric buses.
\end{tabular}

Source: https://oglobo.globo.com/economia/parques-da-disney-vao-ficar-mais-verdes-23153985

Disney, according to the author, has an eye on its reputation, which also consists of a metaphorical expression "to be with an eye on something", that is, to be interested in something. In this case, there is also a metonym for using the term "eye" as a part that represents the whole. In this case, being with one eye is to look at something, to be interested. Radden and Kövecses $(1999$, p. 21) remember that metonymy is also a cognitive process in which one term gives access to another.

Thus, it can be inferred that Disney's reputation is being built around sustainability, that is, carrying out green marketing as a company with social responsibility for being able to supply electricity to the region and also sustainable in order to preserve the environment with less gas emission. In, "Disney is EMERGING AS A RENEWABLE ENERGY FORCE", the author works on the polysemic sense of strength (energy) and strength (will) to say that the company is rising through this sustainable policy. From the statement, it is possible to observe a conceptual metaphor RENEWABLE ENERGY IS STRENGTH TO RISE. In this regard, it is worth remembering that orientational metaphors are used, in line with Lakoff and Johnson (1980), that more is upwards, or even upwards is upwards, in the sense of being something positive. In this case, it is necessary to recognize by the knowledge of the world, in terms of Physics, that for something to rise it is necessary ENERGY.

Therefore, in this reasoning, the author uses the term "emerge" to represent and direct the discourse in the sense that the company is rising, that is, rising in the market with an energy force, which comes from sustainable investments as a strategy for green marketing. Schematically, we have, as shown below, that from the text, one can recognize the conceptual metaphors involved not only in the statement, but also in the arguments that surround it. After all, through him the author leaves clues for the production of effects of meaning. Thus, it can be observed that ENERGY IS FORCE $\rightarrow$ IMPULSE TO RISE / EMERGING, as well as RENEWABLE ENERGY IS FORCE.

Furthermore, it is also worth remembering that all renewable energies themselves are sources of energy and come from a force, whether by the sun, wind, water or chemistry. In this case, it may be that the argument is all built around conceptual metaphors and the mental representations that the reader activates from the schema images around the upward movement $\rightarrow$ ascension $\rightarrow$ energy. In this argumentative field, it can be observed that the term "force" activates other domains to arrive at the conceptual metaphor, such as: force $\rightarrow$ energy $\rightarrow$ rise / emerge $\rightarrow$ renewable energy.

In the title "DISNEY PARKS WILL GET MORE GREEN", it is possible to observe that again the term "green" appears polysemically to relate both to the space of gardens that the park has, and the metonym of "green" as a semantic representation of environmental sustainability. In this sense, the term "more" emphasizes the idea that they are already green, but with the sustainable policy of producing electricity they will become greener because SUSTAINABILITY IS GREEN / RENEWABLE ENERGY. IT'S GREEN. Therefore, it is possible to extract another conceptual metaphor, in which the term "green" is the source domain, just as "Disney parks" are green, in the previous example.

In the excerpt, "In 2015, when FIRST, FOR THE FIRST TIME,“ TURN GREEN” YOUR BUS FLEET, the executives thought that the solution could be the electric buses", the term "green" appears as a way of linguistic updating of the conceptual metaphor already explored around the term "green energy" creating a verb "green". 
It should be noted that the formulation is intended to demonstrate that for the first time, Disney tried to make its bus fleet more sustainable. However, instead of saying it that way, the author opted for the term "turn green" referring to the conceptual metaphor that SUSTAINABILITY IS GREEN / RENEWABLE ENERGY IS GREEN in addition to drawing attention to the metonymic effect of the term.

When saying "In all of our facilities around the world, we are investing in HIDDEN MAGIC to continually reduce our environmental impact", the "hidden magic" metaphor is used as an argument to support the idea that this is a major investment of electricity generation. The term "magic", in this case, can be understood from inferences that may refer to the very show that Disney promotes in its theme park events, as it is known that they all end with a great light show, as well as the effect of sense that the generation of electric energy and the very notion of energy is something that is not in the visible world.

Thus, the term "hidden" as an adjective for the term "magic" complements the meaning of metaphorical use to explain the process of generating electricity. It is known that energy is not something visible, it can only be manifested from a transformation and the interconnection with a visible object. In this sense, it is possible to expose the conceptual metaphor schematically. Magic $\rightarrow$ electricity $\rightarrow$ hidden things $\rightarrow$ Disney show $\rightarrow$ lights.

In "Disney's move towards CLEANER ENERGY occurs at a time when the brand image of GLOBAL GIANTS" NEEDS TO GO MUCH BEYOND, SAY, A SPACE MOUNTAIN RIDE - particularly among the millennial generation, highly consumerist, but concerned with the environment, one can observe the use of metaphor to support the argument of the idea that the Disney movement to produce electricity from renewables is a way of extolling the company's brand in a consumer generation but concerned with sustainability. Therefore, this factor is what the company intends to invest.

For this, the author emphasizes that it is cleaner energy, highlighting the fact that the ENERGY CLEAN metaphor to have more reader support that after all it is a type of non-polluting energy, therefore "cleaner". In addition, the use of the term "global giants" brings up the idea of globalization, that is, that the brand image of a large globally recognized company like Disney needs to go much further, it needs to turn to an audience concerned about the environment.

In this sense, the term "giant" is used to represent "large companies", which associated with global means "large companies recognized worldwide". In this case, both "global giant" and "big company" are both language updates of the same conceptual metaphor. Note that the conceptual metaphor IMPORTANCE IS SIZE can be highlighted here and underlies the expression "global giant".

In the last section "YOU NEED TO GO MUCH BEYOND, SAY, FROM A TOUR IN SPACE MOUNTAIN particularly among the millenium generation, highly consumerist, but concerned with the environment", the metaphor is generated by the analogical comparison between walking on the "space mountain", which is a famous roller coaster and the act of ascending socially and economically in the business field. Since the reader associates with a roller coaster, whose elevations are quite accentuated with the previous passage that Disney is emerging and "needs to go further [...]".Thus, it is noted that there is an entire construction that is considered metaphorical and every argument is made around it. In terms of concept, there is DISNEY IS A GLOBAL GIANT and in terms of green marketing, "Disney cares about the environment". In that case, again, the conceptual metaphor IMPORTANCE IS SIZE can be activated to understand Disney as a global giant.

In terms of mappings, it is possible to understand from the verbal text that the term "giant" is related to the concept of tall and big, which also refers to the idea of a big company, as well as to the one that has a global reputation and therefore, the relationship with "big", because it has a wide "domain" of performance and prominence. In addition, the term "tall and big" also refers to the idea of a roller coaster because it is also tall and big and finally the relationship of this "climb" that the roller coaster has with the act of climbing / ascending at the same time that it also refers to companies that rise globally and become global. From the term giant $\rightarrow$ high / big $\rightarrow$ global $\rightarrow$ to ascend / ascend as a roller coaster.

Considered as the mascot of Disney, the character and his image ended up becoming a symbol, a representation of Disney itself. Associated with the journalistic subject in question, one can have the idea that the image completes at the same time that it seeks to represent its content. In this sense, it can be inferred from the title and the correlation with the image that Disney will be greener due to the installation of photovoltaic plates and this, in metaphorical terms, concerns the generation of green energy. Hence the expression "stay GREENER".

In a schematic representation we have: Mickey is the symbol of Disney and is used, in this case, as a metonym because he is representing Disney. The Disney symbol built with photovoltaic plates refers to the idea that Disney produces renewable energy and, RENEWABLE ENERGY IS GREEN ENERGY. Soon, Disney will get GREEN $\rightarrow$ DISNEY IS GREEN $\rightarrow$ Disney is sustainable. Thus, it is possible to perceive the entire argumentative game from the image / text relationship in the story. 
In the excerpt below, table 9, the metaphor is built around a culturally known expression in Brazil "short blanket on cold days" to represent situations in which the head is covered or the feet are covered. Both, having a short cover, are impossible. Based on a reality that is often experienced by homeless people who normally spend their nights with short blankets, the expression has come to be used semantically to represent difficult situations, especially when you have a very difficult choice to decide.

Table9- Shock energy and diplomacy

\begin{tabular}{|l|}
\hline NEWSPAPER_O FLUMINENSE / Brasil \\
\hline 26/02/2019 13:49 / AddThis Sharing Buttons \\
\hline ENERGY AND SHOCK DIPLOMACY \\
\hline According to an estimate by the Brazilian Institute of Geography and Statistics - IBGE, the population \\
distributed throughout the State of Roraima is close to 600 thousand inhabitants, or 2.57 inhabitants / $\mathrm{km}^{2}$, to \\
have an idea of the low population concentration, only the city of Niterói, in Rio de Janeiro, has more than \\
510 thousand people, or 3,958 inhabitants / $\mathrm{km}^{2}$. As a consequence of this small demographic rate, in \\
addition to the distance from major centers in the country, some investments were and are postponed in that \\
state, especially those in which the cost-benefit ratio represents more sacrifices than advantages, in popular \\
language is the case of the short blanket on cold days, there is always some part of the body out of \\
protection, this is the biggest problem of the electric power deficit in that region. However, when the costs \\
are high and there are alternatives that can meet the demands, without having to produce extra sacrifices, at \\
least at that moment, these hypotheses should not be overlooked, as in the case of the Brazilian relationship \\
with Venezuela through its electricity company, CorporaciónElétrica Nacional SA - Corpoelec.
\end{tabular}

Source: https://www.ofluminense.com.br/pt-br/atualidades/por-outro-lado-energia-e-diplomacia-de-choque

In metaphorical terms the title "Energy and Shock Diplomacity" brings the term "shock" as a form of representation to combat, that is, to go into shock, opposing views, struggles etc. Thus, returning to the context, it is possible to observe that the term "shock" acts as a metaphor for the conflicting situation that can happen if there is no more electricity supply to the northern region of the country, due to problems with which Venezuela faces, confirmed in the section "[...] among other consequences, the cut in the supply of energy to the Brazilian side will remain, which happening, will represent a high price for the new directions of the Brazilian diplomatic political turn".

In this way, diplomacy is named in the text as "shock diplomacy" in view of these possible consequences that the author calls "sequels", another metaphor for the fact of having to import energy from Venezuela. Therefore, in terms of conceptual metaphors, we have that: BRAZILIAN DIPLOMACY IS COMBAT and INVESTMENTS IN ELECTRICITY ARE A SHORT COVER. Schematically there are: diplomacy $\rightarrow$ shock $\rightarrow$ conflicts.In this case, it can be understood that from the verbal text it is possible to correlate the domain of diplomacy that refers to the ability to resolve conflicts. And the text reinforces this idea saying that Brazil is known as a friendly country, but that in the face of the circumstances of Venezuela there are risks of "a definitive rupture or armed conflict in Venezuela", which is why one should think about "[...] new directions for the Brazilian diplomatic political turn". Thus, the author chose to metaphorize in "shock diplomacy". Therefore, there is the conceptual metaphor SHOCK IS CONFLICT. In addition, the text has the idea that INVESTMENTS IN ELECTRIC ENERGY ARE SHORT BLANKETS. In this context, there are: investments $\rightarrow$ inside and outside the coverage $\rightarrow$ short blanket.

\section{Results and discussions}

From the analysis of the materials, both those that involved environmental sustainability in general and those that were more directed towards green energy, it was possible to identify that: There is an expressive number of metaphors / linguistic updates around the term "green". In general, there is a conceptual metaphor that licenses the different language updates identified; The color green has a historical and symbolic representation of nature. The term "green" became popular to the point of spreading throughout the world as a synonym for renewable energy.Points 1, 2 and 3, in this case, are complementary and are related in the constitution of the conceptual metaphor underlying the term "green energy"; The metaphorization of renewable energies as "clean" arose from an attempt to demonstrate that this type of energy does not emit pollutants, even if in terms of minimization; The epididical discourse in these matters on sustainability appears in an attempt to exalt nature and the environment as a natural and common good. It also shows that some companies use this discourse as a green marketing strategy; The conceptual metaphor can be unveiled from inferential developments in the argument.

From the argumentative analysis and identification of the conceptual metaphors that are part of the argumentative process of the epididical discourse, it was possible to establish more evident conceptual domains. "A simple measure of resonance statistics is that the sum of multipilicated occurrences by the sum of the types of metaphors that are from the same domain of origin (Charteris-Black, 2004, p.89).The types are the linguistic forms and the occurrence the number of times that each form appears in the texts. 
Resonance is an indication of the extent to which the metaphor source domains are found in a specific corpus and, therefore, is a measure of its productivity (Charteris-Black, 2004, p.89).

Table 10- Table of resonance

\begin{tabular}{|l|l|l|l|l|}
\hline Sourcedomain & $\begin{array}{l}\text { Types } \\
\text { total }\end{array}$ & $\begin{array}{l}\text { Total } \\
\text { Tokens }\end{array}$ & Ressonance & $\begin{array}{l}\text { \% of total } \\
\text { resonance }\end{array}$ \\
\hline Psychic & 1 & 1 & 1 & 0.57 \\
\hline Health & 1 & 5 & 5 & 8.77 \\
\hline Food & 1 & 1 & 1 & 0.57 \\
\hline Conflict & 1 & 2 & 2 & 3.50 \\
\hline Game & 1 & 1 & 1 & 0.57 \\
\hline Cleaning & 2 & 3 & 6 & 10.52 \\
\hline Body / bodyparts & 4 & 3 & 12 & 21.05 \\
\hline Existence & 1 & 1 & 1 & 0.57 \\
\hline Color & 2 & 5 & 10 & 17.54 \\
\hline Magic & 1 & 1 & 1 & 0,57 \\
\hline Energy / Force & 1 & 2 & 2 & 3.50 \\
\hline Power & 2 & 1 & 2 & 3.50 \\
\hline Clothes & 1 & 1 & 1 & 0.57 \\
\hline Future & 1 & 5 & 5 & 8.77 \\
\hline Law & 1 & 1 & 1 & 0.57 \\
\hline Fashion & 1 & 1 & 1 & 0.57 \\
\hline Life & 4 & 1 & 4 & 7.0 \\
\hline Fire & 1 & 1 & 1 & 0.57 \\
\hline TOTAL & 27 & 36 & 57 & \\
\hline
\end{tabular}

Source: Author date

Therefore, it was possible to identify by the statistical resonance of Charteris-Black (2004) that the conceptual domain body was the most accentuated, very close to the color domain. This indicates that in these speeches, these domains prevail to establish: the first, a connection with the term green, in greater incidence, referring to the symbolism of nature. And the second to metaphors that are related to words that refer to the body, as if the nature should be preserved because it is a fundamental element for the existence of the human body, as a constituent part of it.

Grafic 1 - Types and occurrences

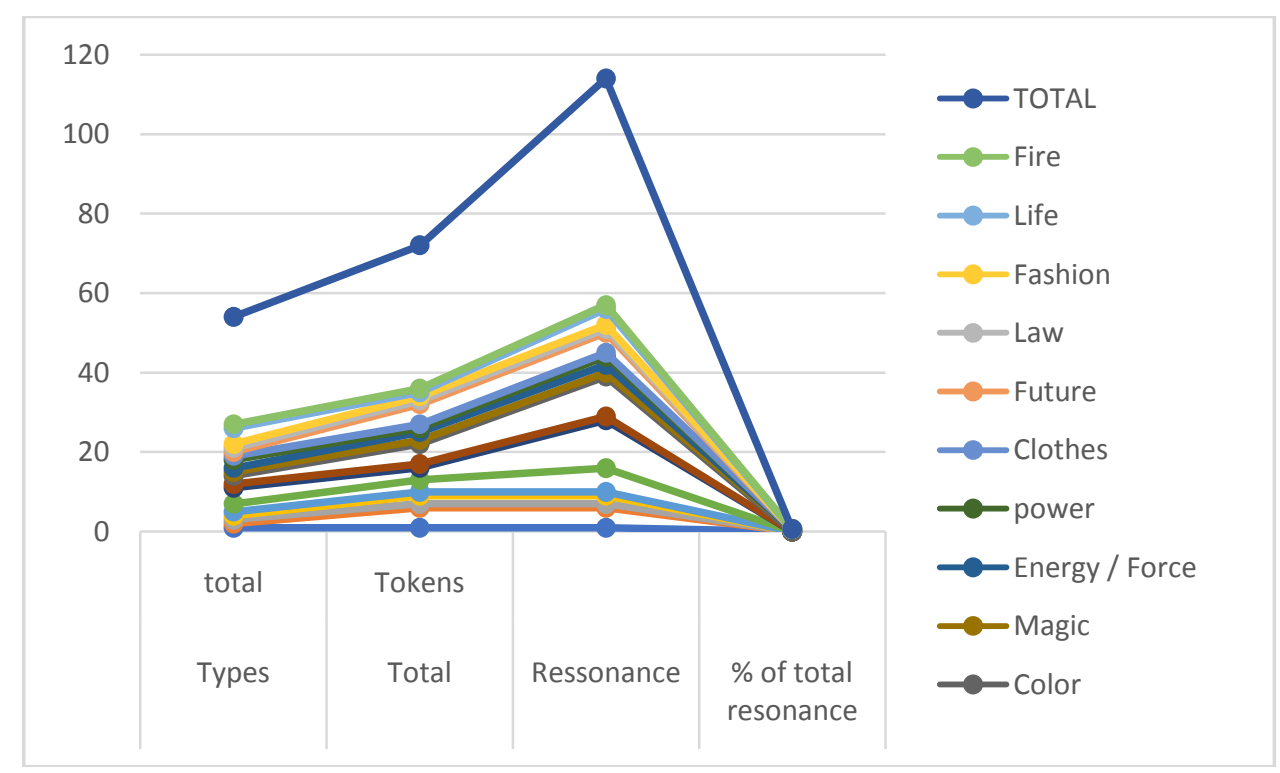

Source: Author date 


\section{Conclusion}

In journalistic articles, as a kind of "portrait" of society, it is possible to understand how metaphor is used in science, especially in engineering that works with terms such as: fossil energy, renewable energy, clean energy and green energy. In general, metaphors are used in science to explain a given phenomenon in an attempt to "translate" the technical-scientific side. These metaphors can be found not only in speeches about environmental sustainability, the focus of this study, but also in other sciences.

In the use of metaphors about environmental sustainability, their presence is also noted as arguments aimed at an epididical discourse, whose objective is to promote sustainable practices for the preservation and conservation of the environment. In this sense, conceptual metaphors collaborate to support this idea. In fact, as an initial premise, it can be seen that metaphors go beyond poetic constructions. They, in turn, consist of a form of reasoning that unfolds in various arguments that guide the reader towards certain effects of meaning.

\section{Referências}

Bonhomme, M. (1998). Les figures clés du discurs. Paris: Seuil.

Charteris-Black, J. (2004). Corpus approaches to critical metaphor analysis. Library of Congress Catatloginf in Publication data.

Cuadrado-Esclapez, G., Arguelles-Alvarez, I., Durán-Escribano, P., Gómez-Ortiz, M.J., Molina-Plaza, S., PierceMcMhon, J., Robisco-Martín, M. M., Roldán-Riejos, A., Úbeda-Masilla, P. (2016).Diccionario bilingue de metáforas y metonímias científico-técnicas: Ingeniería, Arquitectura y Ciencias de la Actividad Física.Partes I \&II Espanol-Inglés, English-Spanish. Grupo de investigacion DISCYT. "Estudios cognitivos y sociopragmáticos del discurso científico y técnico". Universidad politécnica de Madrid. London and New York: Rutledge Taylor \& Francis Group.

CUF - Instituto de oncologia (2019). O órgão. Retrieved of: https://www.saudecuf.pt/oncologia/o-cancro/cancrodo-pulmao/o-orgao.

Finkbeiner, M., Schau, E.M., Lehmann, A., Traverso, M., (2010). Towards life cycle sustainability assessment. Sustainability 2 (10), 3309e3322.

Gentner, D.; Bowdle, B. (2008). Metaphor as structure-mapping. In: GIBBS, R.W. TheCambridge handbook of metaphor and though. New York: Cambridge University Press.

Kövecses, Z. (2005). Metaphor in Culture: universality and variation. New York: Cambridge University Press.

Kövecses, Z. (2007). Variation in Metaphor. In: Revista Ilha do Desterro. Florianópolis, n 53. p. 13-39.

Lakoff, G.; Jhonson, M. (1980). Metaphors we live by. Cambridge: Cambridge UniversityPress, 1980. Metáforas da vida cotidiana. Tradução pelo grupo GEIM. São Paulo: Educ/Campinas: Mercado de Letras, 2002

Larosn, B. (2011). Metaphors for environmental sustainability: redefining our relationship with nature. London: Yale university press.

Maciel, A.M. B. \& Silva, P. V. (2011). A metáfora na terminologiaambiental. In: Congresso Internacional sobre Metáfora na Linguagem e no Pensamento (4, 2011: Porto Alegre). Anais. Porto Alegre: Instituto de Letras da UFRGS.

Perelman, C., Olbrechts-Tyteca, L. (2005). Tratado da argumentação: a nova retórica. Tradução Maria Ermantina de Almeida Prado Galvão; revisão da tradução Eduardo Brandão, 2ed. São Paulo: Martins Fontes.

Praggkejazgroup (20007). Metaphor and symbol,22(1), 1-39, Lawrence Erlbaum Associates, Inc.

Sharachchandra, M. L., Brondizio, E.S., Byrne, J., Mace, G. M., Martinez-Alier, J. (2018). Rethinking Environmentalism: Linking Justice, Sustainability, and Diversity. Edited by Sharachchandra Lele et al. 2018. Strüngmann Forum Reports, vol. 23, series editor Julia Lupp. Cambridge, MA: MIT Press. ISBN 9780262038966.

Sharachchandra, M. L. (1991). Sustainable development: acritical review. WorldDevelopment, vol. 19, no. 6, pp. 607-621.

Tseronis, A., Forceville, C. Multimodal argumentation and rhetoric in media genres. Amsterdam/ Philadelphia: University of Amsterdam, 2017. 